\title{
Effect of CEO Characteristics Toward Tax Aggressiveness: Overview of Indonesia Family Firms
}

\author{
Kukrit Wicaksono ${ }^{1,}$ and Rachmawati Meita Oktaviani ${ }^{2}$ \\ ${ }^{1,2}$ Department of Accounting, Faculty of Economy, Stikubank University, Semarang, Indonesia \\ Email address: \\ *wicaksonoxkukrit@gmail.com \\ *Corresponding author
}

\begin{abstract}
This study aims to examine the relationship between CEO tenure and risk preferences) toward tax aggressiveness of Indonesia family firms. Tax Aggressiveness in this study became the dependent variable, meanwhile the independent variables consisted of CEO tenure and CEO risk preferences. Profitability is also included in the study as a control variable. The family companies listed on IDX during 2016 to 2019 period are used as sample of this research. The data collection method used purposive sampling. The total sample that can be collected through this method is 70 samples with 280 observations. This study uses a panel data regression analysis model with a random effect model estimation model. The results obtained through the regression test indicate that the tenure and risk preferences of the CEO have an effect toward tax aggressiveness.
\end{abstract}

Keywords: CEO tenure, CEO risk preferences, tax aggressiveness, family firms.

\begin{abstract}
Abstrak: Penelitian ini bertujuan untuk menguji hubungan antara masa jabatan CEO dan preferensi risiko CEO terhadap agresivitas pajak perusahaan keluarga Indonesia. Tax Aggressiveness dalam penelitian ini menjadi variabel dependen, sedangkan variabel independennya terdiri dari CEO tenure dan CEO risk preference. Profitabilitas juga dimasukkan dalam penelitian sebagai variabel kontrol. Perusahaan keluarga yang terdaftar di BEI selama periode 2016 hingga 2019 digunakan sebagai sampel penelitian ini. Purposive sampling dijadikan metode pengumpulan data. Jumlah sampel yang dapat dikumpulkan menggunakan metode ini adalah 70 sampel dengan total 280 observasi. Hasil uji estimasi model menunjukkan penggunaan Random Effect Model (REM) sebagai model analisis regresi. Atas hasil analisis regresi dengan model REM membuktikan bahwa masa jabatan dan preferensi risiko CEO berpengaruh terhadap agresivitas pajak.
\end{abstract}

Kata Kunci: Masa Jabatan CEO, Preferensi Risiko CEO, Agresivitas Pajak, Perusahaan Keluarga.

\section{INTRODUCTION}

Taxes are mandatory contributions to country that are owed by individuals or a corporate that is coercive based on the law, the compensation can't be got directly and taxes are used for state needs and for the greatest prosperity of the people (Undang-Undang KUP Dan Peraturan Pelaksanaannya, 2013). Taxes are a source of capital for the country's 
development and accommodate the needs of its people, such as the construction of public facilities, provision of social assistance, salaries for civil servants and state officials, as well as for carrying out other activities. Due to the nature of the tax that is imposed on its citizens, including taxpayers, makes the tax inconsistent with the objectives of the taxpayer, especially corporate taxpayers.

Tax is classified as expense, therefore, in the financial statements, it is defined as tax expense. One of the things a company must have to achieve a competitive advantage in order to be able to compete with competitors is cost leadership (Porter, 1980). To obtain cost leadership, the company must be efficient in every expense incurred, operating expenses, including tax expenses. So that the company will make efforts to minimize the tax expenses. The efforts made to minimize corporate taxes can be categorized as legal actions, which are permitted by tax law, or illegal, which means the company is violating tax regulations. Activities to minimize the tax expense will be more aggressive if indeed the control holder has a relationship with the top management level of company.

Family companies would be more aggressive in regulating their tax expenses (Martinez et al., 2014). In fact, based on the results of a business survey conducted by (PcW, 2014), it was revealed that $95 \%$ of businesses in Indonesia are family companies. Thus, the amount of tax paid by family companies has a role in state income. The government must be able to find out what are the factors in the size of the tax paid by this family company so that the government is able to create regulations that can accommodate the nature of family companies based on (Martinez et al., 2014), that have tendency to be aggressive towards their taxes.

One of the factors within the company that affects the amount of tax paid is the policy maker. Policymakers are generally the top management level of the company. (Hambrick et al., 1984), explains the Upper Echelons Theory which says that all policies made or produced by a company are influenced by top management level who has the power to make decisions, so that the demographic characteristics possessed by the top management level play a role as an input to the resulting company policy. The person in top management level who has the power to decide a policy is the Central Executive Officer (CEO). Therefore, the demographic characteristics possessed by the CEO such as tenure, age, competencies, etc. have an influence on the company policies that are made (Hambrick et al., 1984). One of the policies made by the company is the policy regarding the amount of tax that is calculated to be paid to the state.

Tax aggressiveness is an effort made to minimize the taxes owed by the company. (Frank et al., 2009), state that tax aggressiveness means engineering taxable income is carried out through tax planning, both legally (tax avoidance) and illegal means (tax evasion). This legal form of tax planning is supported by the Government of Indonesia and has a legal umbrella contained in Law No. 28 of 2007 concerning General Provisions on Taxation, Law no. 36 of 2008 concerning Income Tax (PPh), as well as Law no. 42 of 2009 concerning value-added tax (PPN) and tax for the luxury category (PPnBM). Tax aggressiveness needs to be considered, because the results of policy (tax) from a company can impact on the source revenue of state.

The tenure of the CEO is one of the demographic characteristics as described by (Hambrick et al., 1984), which affects the company's policies issued. CEO tenure is how long a person occupies a position as CEO. Previous research conducted by (Astutik et al., 
2020), revealed there is a relationship between CEO tenure and tax aggressiveness. CEO tenure has an effect on corporate tax planning (Goldman et al., 2017). However in (Hariyanto et al., 2018), and (Yuwono et al., 2019), the tenure of the CEO is stated to have no effect on corporate tax aggressiveness. The same result also occurs in (Aliani, 2014), who also proves that the CEO tenure is not significant for tax planning and (Hanafi et al., 2014), who also revealed that the CEO tenure is not significant for tax avoidance.

Another thing that is included in a person's characteristics is the level of courage in taking risks or what is called risk preference. Everyone has their own risk preferences. CEOs of different companies have different individuals, so they have different risk preferences. The nature of individuals who are willing to take risks is called the risk-taker, while the opposite is called the risk-averse. Because this trait is in a person and is a demographic characteristic of that person, according to the Upper Echelons Theory, that the characteristics of the CEO will influence the policies he makes, the CEO's risk preference also has a role in the policies he makes, in this case his aggressiveness to minimize the burden of tax or tax aggressiveness. Executives who tend to be risk-takers have more courage in taking risks in a policy (Hanafi et al., 2014). Different statement comes from (Novita, 2016), who said although the executives character at the companies are basically a risk taker, in the case of tax avoidance, they tend to be more cautious because of taxes law.

Based on the gap between one study and another, this study will examine the relationship between tenure and CEO risk preference toward tax aggressiveness in family firms in Indonesia. This study uses a population and a sample of family companies listed on the Indonesia Stock Exchange (IDX) for the period 2016 to 2019.

\section{THEORITICAL REVIEW}

Upper Echelons Theory. Upper echelons theory is a theory discovered by (Hambrick et al., 1984), which explains the outcome of a company which is the result of policies determined by top management, moreover, the characteristics and capabilities of top management. The upper echelons theory stresses the importance of the manager's role within the firm. According to this theory, the manager can influence the value creation of firms through his style of management and personal skills (Aliani, 2014). Basically, the characteristics of the upper echelon are divided into two, namely psychological and observable (Astutik et al., 2020). Managerial characteristics as an indicator that is inherent in a manager is brought to an administrative situation by him and they are used to decide complex policies. So that Upper Echelons Theory is able to present the relationship between the demographic characteristics of individuals at top level management and their policies or decisions.

Tax Aggressiveness. (Frank et al., 2009), states that tax aggressiveness is reflected in efforts to regulate the tax burden in such a way through tax planning, tax avoidance, and even tax evasion. Tax planning is one of the steps in minimizing the tax expense as a manifestation of tax aggressiveness. Tax planning is a series of plans in regulating the recording of company transactions, which ends up in the financial statements. The accounting arrangements at the tax planning stage constitute legal engineering without violating applicable tax regulations (Pohan, 2018). According to (Pohan, 2018), tax avoidance is an 
effort to streamline the tax expense by avoiding tax imposition by directing it to transactions that are not tax objects. Tax evasion is an attempt by taxpayers to avoid illegally owed taxes by hiding the real situation. Tax evasion is included in the category of violation of tax regulations so that it can be subject to sanctions or criminal acts if it is known by the competent authorities.

CEO Tenure relation toward tax aggressiveness. The CEO is decided at the General Meeting of Shareholders and determined when he will take office until the end of his term of office, this is known as the CEO tenure. The CEO will face various things that must be decided regarding the company's policies in order to carry out the company's strategy. In making these decisions, the CEO will be influenced by the characteristics that exist in him both psychologically and observable (Hambrick et al., 1984). Tenure is one of the observable characteristics of CEO. Based on (Astutik et al., 2020), Upper Echelons Theory explains CEO tenure gives confidence to take a challenging decision in financial. The aggressiveness of a CEO in carrying out his tax planning is included in challenging or risky financial decisions. Because if any tax regulations are violated, the consequences will be dealing with criminal acts. The longer he holds office, the more experienced and courageous the CEO will be in making decisions (Astutik et al., 2020). On the other hand, someone who has just been elected CEO will be more wary of reported corporate taxes. Based on the theoretical description and supporting references that have been explained, the hypothesis is:

H1: CEO tenure has an effect toward tax aggressiveness.

CEO's risk preference relation toward tax aggressiveness. Risk preference commonly refers to the tendency to choose an action that involves higher variance in potential monetary outcomes, relative to another option with a lower variance of outcomes (but equal expected value) (Hertwig et al., 2019). (Hertwig et al., 2019), also said that in psychology, risk preference is often broadly interpreted as the propensity to engage in behaviours or activities that, although rewarding, involve the potential for loss or harm (for oneself or others). (Astutik et al., 2020), state that top management level demographic characteristics in Upper Echelons Theory include psychological and observable dimensions. Thus, it can be said that the CEO's risk preference is a psychological dimension in the characteristics of the CEO that has an influence on the policies made by him. Psychological traits such as risk-aversion, optimism, and risk-tolerant or risk-taking influence CEO in making company decision (Graham et al., 2011). Policies regarding tax planning, how much is the company's tax expense, how to minimize the tax expense but does not violate taxation rules is also the authority of the CEO. Based on the theoretical description and supporting references that have been explained, the hypothesis is:

H2: CEO's risk preference has an effect toward tax aggressiveness.

Research Model. The research model uses a standard regression model as shown in Figure 1. Based on the developed hypothesis, there is a direct relationship between the independent variables, namely CEO tenure and CEO risk preferences with Tax Aggressiveness. 
Profitability as a control variable also has a direct relationship with tax aggressiveness based on evidence of a relationship in previous research (Astutik et al., 2020), (Dewi et al., 2020), (Devi et al., 2019), and (Dwiyanti et al., 2019).



Figure 1. Research Model

Source: data processed, 2021

\section{METHODS}

The study uses panel data which is a combination of cross section data and time series. Documentation technique is used in collecting secondary data. Secondary data can come from company records or documentation, government publications, industry analysis provided by the media, the internet web, and etc. (Sekaran et al., 2017). Annual Financial Statements and company annual reports are used as secondary data for this research, which


method was used. Purposive sampling was carried out with the following criteria: The company was listed in IDX during the period 2016 to 2019. The company meets the criteria of a family company, namely the founder or acquirer is the controlling shareholder who owns at least $25 \%$ of the shares of the company as well as, a member of the founding family or acquirer who is the holder some of these controlling shares serve as company management (Price Waterhouse Cooper (PwC), 2014). The next criterion is that the family company must experience a profit during the 2016-2019 period. The value of the company's CETR ratio must be between 0 and 1 . The last criterion is a company that has complete information about its management profile and financial statements for period 2016-2019.

Tax aggressiveness is how much effort is made to minimize the tax expense. (Frank et al., 2009), states that tax aggressiveness is reflected in efforts to regulate the tax burden in such a way through tax planning, tax avoidance, and even tax evasion. According to (Ross 
et al., 2015), one of the proxies of tax aggressiveness is Cash Effective Tax Rates (CETR) and can be calculated by using its formula as following:

$$
\text { CETR }=\frac{\text { Tax Payment } i \text { period }}{\text { Profit before tax }}
$$

CEO tenure which describes how long a person has been in the CEO position, proxied measured by how many years the CEO has served (Aliani, 2014). The information can be seen in annual report of company. Another independent variable is risk preference Risk preference is the psychological side of a person in the courage to take risks. The nature of being cautious about a risk is called risk-averse. On the other hand, a trait that tends to take risks is called risk-taking. The risk-adjusted measure of EBITDA/Assets is calculated by dividing the average profitability measure EBITDA/Assets by the standard deviation of corporate earnings (RISK) (Novita, 2016). EBITDA (E) is earnings before interest, taxes, and depreciation and (T) is total sample. As CEO is one of the most important decision makers for corporate, then this formula will reflect their risk preference (Novita, 2016). Its formula can be written as following (Novita, 2016):

$$
R I S K=\sqrt{\sum_{T-1}^{T}\left(E-1 / T \sum_{T-1}^{T} E\right)^{\wedge} 2 /(T-1)}
$$

The study uses profitability control variables. Profitability measures the ratio of profits generated by the company through the utilization of the resources used.. The profitability ratio used as a proxy is Return on Assets (ROA). Profitability has been shown to have an effect toward tax aggressiveness by (Darmawan et al., 2014), (Yuwono et al., 2019), (Astutik et al., 2020), (Gunawan et al., 2017). The formula of ROA is written as following:

$$
R O A=\frac{\text { Net Profit }}{\text { Total Assets }}
$$

The study uses panel data regression analysis to examine the relationship between CEO tenure and CEO risk preference on tax aggressiveness. Since the data used is panel data, the first thing to do is test the model estimate. The model estimation test consists of three: Common Effect Model (CEM), Fixed Effect Model (FEM), and Random Effect Model (REM). This model selection is used to accommodate the intercepts and slopes contained in the panel data, so it is necessary to choose which model is the right one. After knowing the appropriate estimation model for the panel data regression test, a classical assumption test can be carried out which consists of: Normality Test, Multicollinearity Test, Autocorrelation Test, and Heteroscedasticity Test. However, based on (Gujarati et al., 2015), testing classical assumptions on panel data regression is not necessary, because panel data has advantages. Testing the relationship between the independent and dependent variables can be done through the t-statistic test which tests the partial relationship between the independent variable and the dependent variable. To test the relationship simultaneously the independent and dependent variables can be done through the F-statistics test. The panel data regression equation used can be written as below: 


$$
\begin{aligned}
& \text { TaxAggressiveness }_{i t}=\alpha_{i t}+\beta 1 \text { CEOTenure }_{i t}+\beta 2 \text { CEORiskPreference }_{i t}+ \\
& \beta 3 R O A_{i t}+\varepsilon_{i}
\end{aligned}
$$

Information:

$\begin{array}{ll}\alpha & =\text { Constant } \\ \beta & =\text { Regression Coefficient } \\ \varepsilon & =\text { Error } \\ \mathrm{i} & =1,2,3, \ldots, \text { (entities) } \\ \mathrm{t} & =1,2,3, \ldots, \text { (years) }\end{array}$

\section{RESULTS}

First, a data search was carried out on IDX to obtain the desired sample. This is done by looking at the fact books provided by IDX each year, then selecting them according to the specified purposive sampling criteria. After the sample meets the criteria found, a search for the required variables is carried out through the annual reports and annual financial reports of each company that is used as the final sample.

\begin{tabular}{|c|c|}
\hline Companies listed on IDX 2016 period & 533 \\
\hline $\begin{array}{l}\text { Companies delisted on IDX during } 2016 \text { - } 2019 \\
\text { periods }\end{array}$ & 28 \\
\hline $\begin{array}{l}\text { Companies did not meet the family firm criteria as } \\
\text { PwC, (2014) mentioned. }\end{array}$ & 392 \\
\hline Companies suffered losses & 39 \\
\hline $\begin{array}{l}\text { Companies have insufficient information of CEO } \\
\text { background }\end{array}$ & 1 \\
\hline $\begin{array}{l}\text { Companies don't have published financial } \\
\text { statements. }\end{array}$ & 1 \\
\hline Companies have CETR value more than 1 . & 2 \\
\hline Final Sample & 70 \\
\hline
\end{tabular}

Table 1. Purposive Sampling Result

The result of the purposive sampling found 70 family firms listed on IDX during 2016 to 2019. The details are as follows: 533 companies were listed on IDX in 2016 period. 28 companies were delisted from 2016 until 2019. 392 companies did not meet the criteria for family companies as in (PwC, 2014). 39 companies suffered losses. One company does not have sufficient information regarding the background of its CEO. One company does not have its financial statements available for a certain period. Two companies have a CETR value of more than 1 . So that the final sample total is 70 companies, with a total observation of 280 . 
Table 2. Hausman Test

Correlated Random Effects - Hausman Test

Equation: Untitled

Test cross-section random effects

\begin{tabular}{|c|c|c|c|c|}
\hline Test Summary & & $\begin{array}{l}\text { Chi-Sq. } \\
\text { Statistic }\end{array}$ & Chi-Sq. d.f. & Prob. \\
\hline Cross-section random & & 4.109289 & 3 & 0.2499 \\
\hline \multicolumn{5}{|c|}{ Cross-section random effects test comparisons: } \\
\hline Variable & Fixed & Random & $\operatorname{Var}$ (Diff.) & Prob. \\
\hline \multicolumn{5}{|c|}{ X2_RISK_PREFERENCES } \\
\hline & 1.012315 & 1.128232 & 41.042580 & 0.9856 \\
\hline X1_TENURE_ & 0.008094 & 0.003071 & 0.000006 & 0.0471 \\
\hline X3_ROA_ & -0.485569 & -0.543916 & 0.003295 & 0.3094 \\
\hline
\end{tabular}

Cross-section random effects test equation:

Dependent Variable: Y_CETR_

Method: Panel Least Squares

Date: 05/08/21 Time: 09:05

Sample: 20162019

Periods included: 4

Cross-sections included: 70

Total panel (balanced) observations: 280

\begin{tabular}{crrrr}
\hline \hline Variable & Coefficient & Std. Error & t-Statistic & Prob. \\
\hline \hline X2_RISK_PREFERENCES & 0.149046 & 0.139198 & 1.070745 & 0.2855 \\
& & & & \\
X1_TENURE_ & 1.012315 & 6.426552 & 0.157521 & 0.8750 \\
X3_ROA_ & 0.008094 & 0.002812 & 2.878665 & 0.0044 \\
\hline \hline & -0.485569 & 0.140441 & -3.457453 & 0.0007 \\
\hline \hline
\end{tabular}

Cross-section fixed (dummy variables)

\begin{tabular}{llll}
\hline \hline Root MSE & 0.055260 & R-squared & 0.810590 \\
Mean dependent var & 0.225350 & Adjusted R-squared & 0.744708 \\
S.D. dependent var & 0.127201 & S.E. of regression & 0.064270 \\
Akaike info criterion & -2.432093 & Sum squared resid & 0.855039 \\
Schwarz criterion & -1.484451 & Log likelihood & 413.4930 \\
Hannan-Quinn criter. & -2.051992 & F-statistic & 12.30369 \\
Durbin-Watson stat & 1.878769 & Prob(F-statistic) & 0.000000 \\
\hline \hline
\end{tabular}

Based on the Model Estimation Test, it can be determined that the panel data regression model suitable for use is the Random Effect Model (REM). The Chow Test result states that the probability of the Chi-Square Cross Section is $0.000<0.05$. So based on this 
result, it is necessary to do the Hausman Test. The Hausman test result states that the probability of the Chi-Square Cross Section is $0.2499>0.05$. Based on these results, a final test is needed to determine whether the selected REM or CEM model is through the Lagrange Multiplier Test (LM Test). The LM test yields that probability of Breusch-Pagan is 0.0000 . Thus, it can be determined that the appropriate estimation model for this research data is REM.

Table 3. Descriptive Statistics

\begin{tabular}{lcccc}
\hline & & & (RISK & \\
& $($ CETR) & (TENURE) & REFERENCES) & (ROA) \\
\hline Mean & 0.225350 & 10.67143 & 0.020888 & 0.064296 \\
Median & 0.239949 & 8.000000 & 0.014935 & 0.048737 \\
Maximum & 0.814617 & 48.00000 & 0.217847 & 0.455579 \\
Minimum & 0.000000 & 1.000000 & 0.000701 & 0.000526 \\
Std. Dev. & 0.127201 & 9.938479 & 0.027246 & 0.056854 \\
\hline
\end{tabular}

Based on the results of descriptive statistics in the table 3 , the average value for the dependent variable, tax aggressiveness is 0.225350 . The median of tax aggressiveness is 0.239949 , while the maximum value is 0.814617 , and the minimum value is 0 . The standard deviation of the tax aggressiveness variable is 0.127201 . Table 3 also shows that the average value of variable independent, tenure, is 10.67143 . The median value of tenure is 8 , while the maximum value is 48 and the minimum value is 1 . Standard deviation of tenure is 9.938479. The average value of risk preferences variable is 0.020888 , the median is 0,014935 . Maximum value of risk preferences is 0.217847 , and minimum value is 0.000701 . Standard deviation of risk preferences is 0.027246 . Control variable, ROA, has the average value 0.064296 . The median is 0.048737 . The maximum value of ROA is 0.455579 , while the minimum value is 0.000526 . Standard deviation of ROA is 0.056854 .

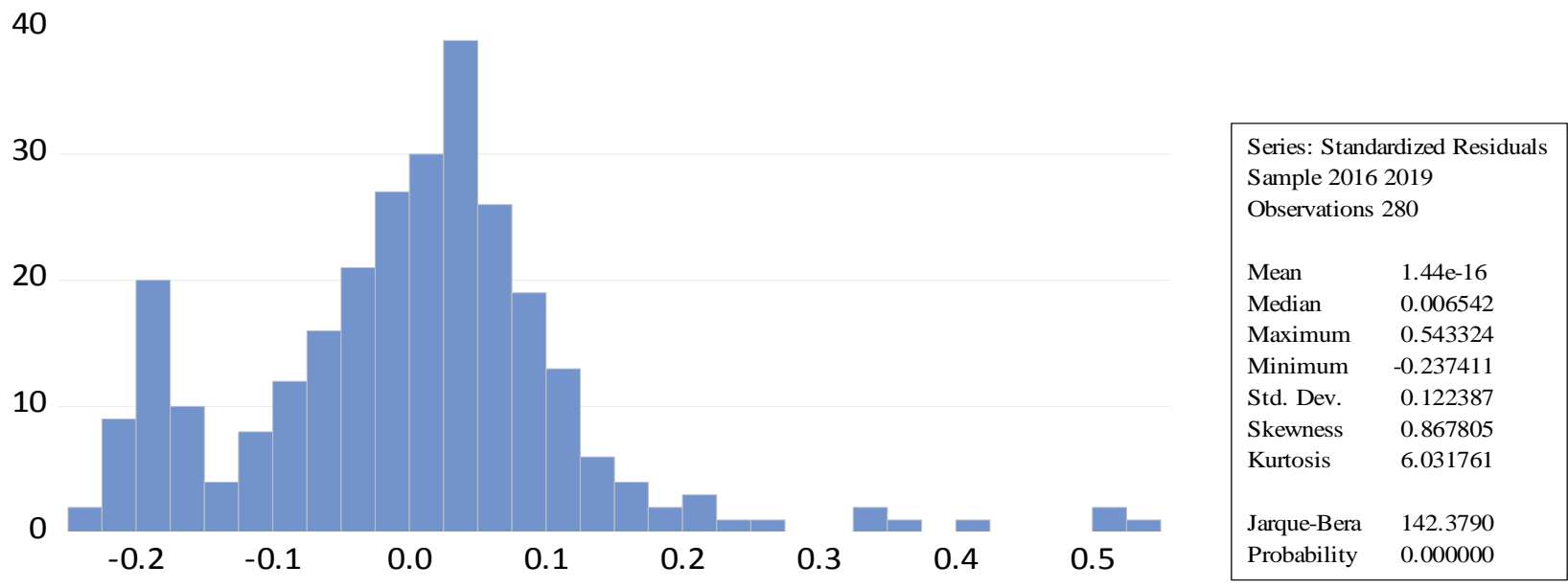

Figure 2. Normality Test

The normality test can be done through the Jarque-Bera probability value. The data residual distribution is said to be normal if the Jarque-Bera probability is $>0.05$. In Table 3 
the Normality Test, can be seen that the Jarque-Bera probability is $0.0000<0.05$. Violation of the assumption of normality on a large enough sample size (>30 or 40) does not cause major problems, and if the sample consists of hundreds of observations, the data distribution can be ignored because the distribution of the sampling error term is close to normal (Ghasemi et al., 2012). Based on that statement, the problem of normality of the research data can be ignored because this study uses a sample of 70, and the total observation is 280 .

Table 4. Multicollinearity Test

\begin{tabular}{lccc}
\hline & (TENURE) & (RISK & (ROA) \\
\hline (TENURE) & 1 & -0.119637 & 0.074659 \\
(RISK PREFERENCES) & -0.119637 & 1 & 0.487066 \\
(ROA) & 0.074659 & 0.487066 & 1
\end{tabular}

The next classic assumption test is multicollinearity. Table 4 shows that the correlation value between the independent variables is less than 0.8 . If the correlation value between the independent variables is less than 0.8 , this indicates that there are no symptoms of multicollinearity (Ghozali et al., 2017).

Table 5. Autocorrelation Test

Dependent Variable: D(Y_CETR_)

Method: Panel EGLS (Cross-section random effects)

Date: 05/08/21 Time: 09:27

Sample (adjusted): 20172019

Periods included: 3

Cross-sections included: 70

Total panel (balanced) observations: 210

Swamy and Arora estimator of component variances

\begin{tabular}{ccccc}
\hline Variable & Coefficient & Std. Error & t-Statistic & Prob. \\
\hline C & 0.003163 & 0.006731 & 0.469875 & 0.6389 \\
D(X1_TENURE_ $)$ & 0.008819 & 0.004297 & 2.052496 & 0.0414 \\
D(X2_RISK_PREFERENCES_) & 0.623059 & 7.252853 & 0.085905 & 0.9316 \\
D(X3_ROA_) & -0.400523 & 0.144647 & -2.768971 & 0.0061 \\
\hline
\end{tabular}

\begin{tabular}{|c|c|c|c|c|}
\hline \multicolumn{5}{|c|}{ Effects Specification } \\
\hline & & & S.D. & Rho \\
\hline Cross-section random & & & 0.000000 & 0.0000 \\
\hline Idiosyncratic random & & & 0.082863 & 1.0000 \\
\hline \multicolumn{5}{|c|}{ Weighted Statistics } \\
\hline Root MSE & 0.075763 & R-squared & & 0.068682 \\
\hline Mean dependent var & 0.011401 & Adjusted R-squared & & 0.055119 \\
\hline S.D. dependent var & 0.078695 & S.E. of regression & & 0.076495 \\
\hline Sum squared resid & 1.205407 & F-statistic & & 5.063949 \\
\hline
\end{tabular}




\begin{tabular}{lllr} 
Durbin-Watson stat & $\mathbf{1 . 8 4 1 1 4 8}$ & Prob(F-statistic) & 0.002099 \\
\hline & Unweighted Statistics & \\
\hline & & & \\
R-squared & 0.068682 & Mean dependent var & 0.011401 \\
Sum squared resid & 1.205407 & Durbin-Watson stat & 1.841148 \\
\hline
\end{tabular}

The autocorrelation test is seen in the Durbin-Watson value in Table 5. Autocorrelation test is performed by regressing the differences of each variable, dependent, independent, and control. Next, we have to find the $\mathrm{dL}$ and dU values based on the number of observations or $n=280$, the number of independent and control variables used in this study or called $\mathrm{k}=3$ with a significance level of $5 \%$ on the Durbin-Watson table. Based on the values of $\mathrm{n}$ and $\mathrm{k}$ in the Durbin-Watson Table, it is known that the value of $\mathrm{dL}$ is 1,78970, and the value of $\mathrm{dU}$ is 1,81123 . So, the value of $4-\mathrm{dL}$ is 2,2103 , and $4-\mathrm{dU}$ is 2,1887. In Table 5 the Durbin-Watson value is 1,841148 . Therefore, the Durbin-Watson value of 1,8411 is between dU, 1,81123 and 4-dU 2,1887 which means that there is no autocorrelation.

Table 6. Heteroscedasticity Test

\begin{tabular}{|c|c|c|c|c|}
\hline \multicolumn{5}{|c|}{$\begin{array}{l}\text { Dependent Variable: RESABSREM } \\
\text { Method: Panel EGLS (Cross-section random effects) } \\
\text { Date: 05/08/21 Time: 09:16 } \\
\text { Sample: } 20162019 \\
\text { Periods included: } 4 \\
\text { Cross-sections included: } 70 \\
\text { Total panel (balanced) observations: } 280 \\
\text { Swamy and Arora estimator of component variances }\end{array}$} \\
\hline Variable & Coefficient & Std. Error & t-Statistic & Prob. \\
\hline $\begin{array}{c}\text { C } \\
\text { X1__TENURE } \\
\text { X2_RISK_PREFERENCES } \\
\text { X3__ROA }\end{array}$ & $\begin{array}{r}0.115656 \\
-0.001369 \\
0.175192 \\
-0.256872\end{array}$ & $\begin{array}{l}0.014252 \\
0.000790 \\
0.319169 \\
0.104401\end{array}$ & $\begin{array}{r}8.115060 \\
-1.732244 \\
0.548899 \\
-2.460431\end{array}$ & $\begin{array}{l}0.0000 \\
0.0843 \\
0.5835 \\
0.0145\end{array}$ \\
\hline \multicolumn{5}{|c|}{ Effects Specification } \\
\hline $\begin{array}{l}\text { Cross-section random } \\
\text { Idiosyncratic random }\end{array}$ & & & $\begin{array}{l}0.061783 \\
0.056492\end{array}$ & $\begin{array}{l}0.5446 \\
0.4554\end{array}$ \\
\hline \multicolumn{5}{|c|}{ Weighted Statistics } \\
\hline $\begin{array}{l}\text { Root MSE } \\
\text { Mean dependent var } \\
\text { S.D. dependent var } \\
\text { Sum squared resid } \\
\text { Durbin-Watson stat }\end{array}$ & $\begin{array}{l}0.055934 \\
0.036668 \\
0.057015 \\
0.876005 \\
1.422176 \\
\text { Unweighte }\end{array}$ & $\begin{array}{l}\text { R-squared } \\
\text { Adjusted R-sc } \\
\text { S.E. of regres } \\
\text { F-statistic } \\
\text { Prob(F-statist } \\
\text { Statistics }\end{array}$ & ared & $\begin{array}{l}0.034117 \\
0.023618 \\
0.056338 \\
3.249652 \\
0.022311\end{array}$ \\
\hline $\begin{array}{l}\text { R-squared } \\
\text { Sum squared resid }\end{array}$ & $\begin{array}{l}0.055850 \\
1.889566\end{array}$ & $\begin{array}{l}\text { Mean depend } \\
\text { Durbin-Watsc }\end{array}$ & $\begin{array}{l}\text { var } \\
\text { stat }\end{array}$ & $\begin{array}{l}0.088190 \\
0.659322\end{array}$ \\
\hline
\end{tabular}


The heteroscedasticity test uses the Glejser test, namely by regressing the absolute value of the residuals on the independent and control variables, if the probability result is more than 0.05 , then the data are free from heteroscedasticity symptoms (Ghozali et al., 2017). The results of absolute residual regression on the independent and control variables used in this study are shown in Table 6 . In Table 6, it can be seen that the probability of the independent and control variables $>0.05$, so this indicates that the data used in this study are free from heteroscedasticity symptoms.

(Gujarati et al., 2015), state that panel data has implications that do not have to test classical assumptions. In addition, panel data has advantages such as: Panel data is considered to provide more information, variation, efficiency and more degrees of freedom and less collinearity between variables because it combines time series observations with cross sections. Panel data can overcome heterogeneity through modeling estimation techniques. Panel data minimizes bias. Complex behavior models can be studied easily by panel data, and panel data can detect and measure impacts in a simple manner (Gujarati et al., 2015)

Table 7. Regression Results

\begin{tabular}{|c|c|c|c|c|}
\hline \multicolumn{5}{|c|}{$\begin{array}{l}\text { Dependent Variable: Y_CETR_- } \\
\text { Method: Panel EGLS (Cross-section random effects) } \\
\text { Date: 05/08/21 Time: 09:02 } \\
\text { Sample: } 20162019 \\
\text { Periods included: } 4 \\
\text { Cross-sections included: } 70 \\
\text { Total panel (balanced) observations: } 280 \\
\text { Swamy and Arora estimator of component variances }\end{array}$} \\
\hline Variable & Coefficient & Std. Error & t-Statistic & Prob. \\
\hline $\begin{array}{c}\text { C } \\
\text { X2_RISK_PREFERENCES } \\
\text { X1_TENURE_ } \\
\text { X3__ROA_ }\end{array}$ & $\begin{array}{c}0.203980 \\
1.128232 \\
0.003071 \\
-0.543916\end{array}$ & $\begin{array}{l}0.022555 \\
0.507931 \\
0.001226 \\
0.128174\end{array}$ & $\begin{array}{c}9.043596 \\
2.221232 \\
2.505388 \\
-4.243569\end{array}$ & $\begin{array}{l}0.0000 \\
0.0271 \\
0.0128 \\
0.0000\end{array}$ \\
\hline \multicolumn{5}{|c|}{ Effects Specification } \\
\hline $\begin{array}{l}\text { Cross-section random } \\
\text { Idiosyncratic random }\end{array}$ & Weighted & Statistics & $\begin{array}{l}0.106518 \\
0.064270\end{array}$ & $\begin{array}{l}0.7331 \\
0.2669\end{array}$ \\
\hline $\begin{array}{l}\text { Root MSE } \\
\text { Mean dependent var } \\
\text { S.D. dependent var } \\
\text { Sum squared resid } \\
\text { Durbin-Watson stat }\end{array}$ & $\begin{array}{r}0.063937 \\
0.065088 \\
0.066829 \\
1.144634 \\
1.431712 \\
\text { Unweighte }\end{array}$ & $\begin{array}{l}\text { R-squared } \\
\text { Adjusted R- } \\
\text { S.E. of regr } \\
\text { F-statistic } \\
\text { Prob(F-stati } \\
\text { d Statistics }\end{array}$ & $\begin{array}{l}\text { quared } \\
\text { sion } \\
\text { ic) }\end{array}$ & $\begin{array}{l}0.081391 \\
0.071407 \\
0.064399 \\
8.151477 \\
0.000032\end{array}$ \\
\hline $\begin{array}{l}\text { R-squared } \\
\text { Sum squared resid }\end{array}$ & $\begin{array}{l}0.074253 \\
4.179022\end{array}$ & $\begin{array}{l}\text { Mean deper } \\
\text { Durbin-Wat }\end{array}$ & $\begin{array}{l}\text { ent var } \\
\text { on stat }\end{array}$ & $\begin{array}{l}0.225350 \\
0.392146\end{array}$ \\
\hline
\end{tabular}


Table 7 shows the results of panel data regression with the estimation model used is REM. The R-squared value in the regression results in Table 7 is 0,081391 or $8,14 \%$. This shows the level of ability of the independent variables, namely CEO tenure and CEO's risk preferences as well as profitability as control variables can explain the dependent variable by $8,14 \%$, the remaining $91,86 \%$ is explained by other variables outside of this study. Simultaneous test results viewed through the F-statistic show a value of 0.000032 which is less than the significant level of 0.05 . This value indicates that the independent and control variables simultaneously influence tax aggressiveness.

The partial test results shown by the t-statistic show that the probability value of $t$ statistic. In the regression results as shown in Table 7, the coefficient of the CEO tenure variable is 0,003071 , While the probability is 0.0128 which means less than the significance level of 0.05 . The coefficient for the CEO risk preference variable is 1.128232 , and the probability value is 0.0271 which also means less than the 0.05 significance level. The probability control variable has a coefficient -0.543916 and a probability value 0.0000 . So that the panel data regression equation can be written as below:

$$
\begin{aligned}
\text { TaxAggressiveness }_{i t}= & 0.203980_{i t}+0.003071 \text { CEOTenure }_{i t}+ \\
& 1.128232 \text { CEORiskPreference } \\
& \varepsilon_{i t}-0.543916 R O A_{i t}+
\end{aligned}
$$

\section{DISCUSSION}

CEO tenure relation toward tax aggressiveness. The hypothesis $\mathrm{H}_{1}$ states that CEO tenure has an effect toward tax aggressiveness. Result of the probability value of this variable is 0,0128 , it is less than significance level of 0.05 . Thus, it is stated that $H_{1}$ is accepted. In this study, it is evident CEO tenure has an effect toward tax aggressiveness carried out in family companies. The positive value of variable regression coefficient of CEO tenure means that the longer a person occupies the CEO position, the more aggressive in minimizing the tax burden of the family company he leads. These results are the same as those shown by research by (Goldman et al., 2017), and (Astutik et al., 2020). Upper Echelons Theory shows that the more complex a decision, the more important personal characteristics of decision makers such as age, tenure and special expertise (Aliani, 2014). Tax aggressiveness that is manifested through tax planning or tax avoidance or other things that minimize the company's tax burden is one of the financial decisions faced by a CEO. Based on the results of this study and related previous research, it shows that the tenure of the CEO influences tax aggressiveness.

CEO's risk preference relation tow ard tax aggressiveness. A person's courage in making a decision depends on the level of courage in taking risks or it can be called risk preference. Therefore, each individual has different risk preferences. The second hypothesis or $\mathrm{H}_{2}$ states that CEO's risk preference has an effect toward tax aggressiveness. Based on the panel data regression results in Table 7, the probability value of the CEO risk preference variable is less than the significance level, this indicates that $\mathrm{H}_{1}$ is accepted. CEO's risk preference influences tax aggressiveness of family firms. CEOs who considerer as risk-taker is more aggressive toward tax (Astutik et al., 2020). Risk preference is one of the psychological 
factors in which this psychological factor is stated by (Hambrick et al., 1984), in Upper Echelons Theory which he puts forward is a demographic characteristic of top management level that will influence managers of top management level in making financial decision. Executive who consider to be risk taker has higher effect on corporate tax avoidance than risk averse (Hanafi et al., 2014). Executives who are risk takers will be more courageous to take risky actions or policies to generate greater cash flow for the company, in this case one of the ways is through tax avoidance (Amri, 2017). These statements relate to the results of this study that the higher the risk preference of a CEO, the greater the tax aggressiveness.

Relationship Between Profitability and Tax Aggressiveness. This study also uses profitability as measured by ROA as a control variable. The regression results show that the probability of the control variable is 0.0000 which is less than the 0.05 significance level. Therefore, it is stated that profitability as measured by ROA influences tax aggressiveness of family firms. This statement in line with the research results of (Astutik et al., 2020), (Dewi et al., 2020), (Devi et al., 2019), and (Dwiyanti et al., 2019).

\section{CONCLUSION}

Taxes are the main source of revenue for the state to carry out all its activities. Therefore, the state will try to maximize the realization of tax revenue to get a bigger state income. Meanwhile, tax is a burden for the company. More than $90 \%$ of the types of companies in Indonesia are family companies. Meanwhile, based on (Martinez et al., 2014) family companies tend to be more tax aggressive. Therefore, the government needs to know what factors influence the tax aggressiveness of the family company to make regulations that are able to accommodate the nature of family companies that tend to be tax aggressive, in other words, family companies will make greater efforts to minimize the tax burden of their companies.

Based on the results, the CEO's demographic characteristics have an effect on tax aggressiveness. These factors are how long the CEO of the family company has served or is known as the tenure of the CEO. Another factor is the risk preference of CEO, if the CEO is bold in taking the risk, he will be more aggressive toward tax.

This study has limitation, namely the low R-Squared value, which means that there are other variables outside of this study that affect tax aggressiveness. Therefore, further research must add other variables to increase the R-Squared value. There is also another proxies to measure tax aggressiveness. So that further research is able to combine measures of tax aggressiveness to make statements about the factors that influence tax aggressiveness more accurately. 


\section{REFERENCES}

Ali, A., and Zhang, W. (2015). CEO tenure and earnings management. Journal of $\begin{array}{lll}\text { Accounting } \text { and 60-79. } & \text { 59(1), }\end{array}$ https://doi.org/10.1016/j.jacceco.2014.11.004.

Aliani, K. (2014). CEO characteristics and corporate tax planning evidence from US companies. International Journal of Managerial and Financial Accounting, 6(1), 4959. https://doi.org/10.1504/IJMFA.2014.060508.

Amri, M. (2017). Pengaruh Kompensasi Manajemen Terhadap Penghindaran Pajak Dengan Moderasi Diversifikasi Gender Direksi Dan Preferensi Risiko Eksekutif Perusahaan Di Indonesia. Jurnal ASET (Akuntansi Riset), 9(1), 1. https://doi.org/10.17509/jaset.v9i1.5253.

Astutik, D., and Venusita, L. (2020). The Influence of CEO's Demographic Characteristics on Tax Aggressiveness in Family Firm. Jurnal Akuntansi Dan Keuangan, 22(1), 1-9. https://doi.org/10.9744/jak.22.1.1-9.

Darmawan, I., dan Sukartha, I. (2014). Pengaruh Penerapan Corporate Governance, Leverage, Roa, Dan Ukuran Perusahaan Pada Penghindaran Pajak. E-Jurnal Akuntansi, 9(1), 143-161.

Devi, shintya; Dewi, Dewa Ayu Nyoman Krisna; Gede, L. (2019). Pengaruh Profitabilitas pada Agresivitas Pajak dengan Pengungkapan CSR Sebagai Variabel Moderasi. EJurnal Akuntansi, 27, 792. https://doi.org/10.24843/eja.2019.v27.i01.p29.

Dewi, K. S., and Yasa, G. W. (2020). The Effects of Executive and Company Characteristics on Tax Aggressiveness. Jurnal Ilmiah Akuntansi Dan Bisnis, 15(2), 280. https://doi.org/10.24843/jiab.2020.v15.i02.p10.

Duan, T., Ding, R., Hou, W., and Zhang, J. Z. (2018). The burden of attention: CEO publicity and tax avoidance. Journal of Business Research, 87(0), 90-101. https://doi.org/10.1016/j.jbusres.2018.02.010.

Dwiyanti, I. A. I., dan Jati, I. K. (2019). Pengaruh Profitabilitas, Capital Intensity, dan Inventory Intensity pada Penghindaran Pajak. E-Jurnal Akuntansi, 27, 2293. https://doi.org/10.24843/eja.2019.v27.i03.p24.

Farag, H., and Mallin, C. (2016). The influence of CEO demographic characteristics on corporate risk-taking: evidence from Chinese IPOs. European Journal of Finance, 24(16), 1528-1551. https://doi.org/10.1080/1351847X.2016.1151454.

Frank, Mary Margaret; Lynch, Luann J.; Rego, S. O. (2009). Tax Reporting Aggressiveness and Its Relation to Aggressive Financial Reporting.

Ghasemi, A., and Zahediasl, S. (2012). Normality tests for statistical analysis: A guide for non-statisticians. International Journal of Endocrinology and Metabolism, 10(2), 486-489. https://doi.org/10.5812/ijem.3505.

Ghozali, Imam; Ratmono, D. (2017). Analisis Multivariat Dan Ekonomometrika. Semarang: Badan Penerbit Universitas Diponegoro Semarang.

Goldman, Nathan C.; Powers, Kathleen; Williams, B. M. (2017). How Does CEO Tenure Affect Corporate Income Tax Planning and Financial Reporting Decision. 16891699.

Graham, J. R., Harvey, C. R., and Puri, M. (2011). Managerial Attitudes and Corporate Actions. SSRN Electronic Journal, (May). https://doi.org/10.2139/ssrn.1432641. 
Gujarati, Damodar N.; Dawn, C. P. (2015). Dasar-Dasar Ekonometrika Edisi 5 Buku 2. Jakarta: Salemba Empat.

Gunawan, H., and Melisa. (2017). The Relationship between Gender and Tax Payments. Journal of Apllied Accounting and Taxation, 2(2), 209-215.

Hambrick, D. C., and Mason, P. A. (1984). Echelons : of Reflection The Its Organization as Top a. Academy of Management Review, 9(2), 193-206.

Hanafi, Umi; Harto, P. (2014). Analisis Pengaruh Kompensasi Eksekutif, Kepemilikan Saham Eksekutif Dan Preferensi Risiko Eksekutif Terhadap Penghindaran Pajak Perusahaan. Diponegoro Journal of Accounting, 3(2), 1162-1172.

Hariyanto, F., dan Utomo, D. C. (2018). Pengaruh Ccorporate Governance dan Kompensasi Eksekutif Terhadap Agresivitas Pajak (Studi Empiris Perusahaan Jasa Sektor Keuangan yang Terdaftar di BEI Tahun 2014 - 2016). Diponegoro Journal of Accounting, 7(4), 1-14.

Hertwig, R., Wulff, D. U., and Mata, R. (2019). Three gaps and what they may mean for risk preference. Philosophical Transactions of the Royal Society of London. Series B, Biological Sciences, 374(1766), 20180140. https://doi.org/10.1098/rstb.2018.0140.

Kristanto, A. B. (2017). Faktor Finansial Dan Non Finansial Yang Mempengaruhi Agresivitas Pajak Di Indonesia. Media Riset Akuntansi, Auditing Dan Informasi, 16(1), 53. https://doi.org/10.25105/mraai.v16i1.2058.

Martinez, A. L., and Ramalho, G. C. (2014). Family Firms and Tax Aggressiveness in Brazil. International Business Research, 7(3), 129-136. https://doi.org/10.5539/ibr.v7n3p129.

Novita, N. (2016). Executives Characters, Gender and Tax Avoidance: A Study on Manufacturing Companies in Indonesia. 15, 92-95. https://doi.org/10.2991/gcbme16.2016.15.

Pohan, C. A. (2018). Manajemen Perpajakan. Jakarta: Gramedia.

Porter, M. E. (1980). Books by competitive strategy.

Price Waterhouse Cooper (PwC). (2014). Survey bisnis keluarga 2014. November 2014, (November), 1-35. Retrieved from https://www.pwc.com/id/en/publications/assets/indonesia-report-family-businesssurvey-2014.pdf.

Ross, S. A; Westerfield, R. W.; Jordan, B. D.; Liim, J.; Tan, R. (2015). Pengantar Keuangan Perusahaan. Jakarta: Salemba Empat.

Sari, P., and Prihandini, W. (2019). Corporate Social Responsibility and Tax Aggressiveness in Perspective Legitimacy Theory. International Journal of Economics, Business and Accounting Research (IJEBAR), 3(04), 330-343. https://doi.org/10.29040/ijebar.v3i04.726.

Sekaran, Uma; Bougie, R. (2017). Metodologi Penelitian Bisnis. Jakarta: Salemba Empat.

Subagiastra, K., Arizona, I. P. E., dan Mahaputra, I. N. K. A. (2017). Pengaruh Profitabilitas, Kepemilikan Keluarga, dan Good Corporate GovernanceTerhadap Penghindaran Pajak (Studi pada Perusahaan Manufaktur di Bursa Efek Indonesia). Jurnal Ilmiah Akuntansi, 1(2), 167-193. https://doi.org/10.23887/jia.v1i2.9994.

Tanaka, M., and Sawada, Y. (2015). Risk preference of managers and firm investments in Lao PDR. Disaster Risks, Social Preferences, and Policy Effects: Field Experiments in Selected ASEAN and East Asian Countries', (34), 265-283. 
Undang-Undang KUP dan Peraturan Pelaksanaannya. (2013). In Perubahan Ketiga UU Nomor 6 Tahun 1983. Jakarta: Kementerian Keuangan Republik Indonesia. Retrieved from www.pajak.go.id.

Yuwono; Fuad. (2019). Pengaruh Corporate Governance Dan Kompensasi Eksekutif Terhadap Agresivitas Pajak. Diponegoro Journal of Accounting, 8(3), 1-12.

\section{ACKNOWLEDGEMENTS}

Thank you to God Almighty who gave all knowledge and convenience in this research, beloved mother and father, thank you for all friends of Unisbank Semarang especially Akuntansi R2 Class. Thank you Unisbank for supporting us in this research. 